\title{
Knowledge Relations of Midwives to The Handling of Corona Virus Infection (Covid-19) on Maternity Mothers in Hospital X
}

\author{
Syefira Ayudia Johar* \\ Faculty of Public Health, Veteran Bangun Nusantara Sukoharjo University. \\ * syefira48@gmail.com
}

\begin{abstract}
Coronavirus $(\mathrm{CoV})$ is a large family of viruses that causes diseases ranging from mild to severe symptoms. The increase in the number of COVID-19 cases lasts fairly quickly and there has been a spread outside of the Wuhan region and other countries. Globally it reported 51,857 cases of confirmation in 25 countries with 1,669 deaths (CFR 3.2\%). Prevention of Covid-19 is influenced by several factors, one of which is knowledge. To date, knowledge of the COVID19 infection in conjunction with pregnancy and the fetus is still limited and there has been no specific recommendation for the treatment of pregnant women with COVID-19.

The purpose of this research is to know the knowledge of midwives to the handling of Corona virus infection (Covid 19) on maternity mothers in hospital X. Research using the research design of cross sectional. Samples amounting to 30 midwives with sample techniques using sampling quotas. Analysis techniques using the Chi Square test.

Results showed that there was a relationship between the knowledge of midwives to the handling of Corona virus infection (Covid 19) on maternity mothers in hospitals X.
\end{abstract}

Kata Kunci : Knowledge, Treatment, Corona Virus Infection, Maternity Mother 


\section{STRADA Jurnal Ilmiah Kesehatan}

DOI: $10.30994 /$ sjik.v9i1.324

ISSN: 2252-3847 (print); 2614-350X (online)

Vol.9 No.1. May 2020. Page.297-302

\section{INTRODUCTION}

Coronavirus $(\mathrm{CoV})$ is a large family of viruses that causes diseases ranging from mild to severe symptoms. There are at least two types of coronavirus that are known to cause diseases that can cause severe symptoms such as Middle East Respiratory Syndrome (MERS) and Severe Acute Respiratory Syndrome (SARS). Coronavirus Disease (COVID-19) is a new type of virus that has never been identified before in humans. Corona viruses are zoonoosis (transmitted between animals and humans). The research mentions that SARS are transmitted from the Mongoose cats (civet cats) to humans and MERS from camels to humans (Pocket book prevention Covid-19, 2020).

Common signs and symptoms of coronavirus infection include the symptoms of acute respiratory disorders such as fever, cough and shortness of breath. In severe cases can cause pneumonia, acute respiratory syndrome, renal failure, and even death. WHO (2019) said China Country Office reported cases of pneumonia unknown etymological in Wuhan City, Hubei Province, China. China identifies pneumonia that is unknown to the etymological type as a new coronavirus (coronavirus disease, COVID-19). WHO has established the Public Health Emergency of International Concern (PHEIC) (WHO, 2020).

COVID-19 infections may cause mild, moderate or severe symptoms. The main clinical symptoms that arise are fever (temperature > 38C), cough and difficulty breathing. In addition, it can be accompanied by shortness of memberat, fatigue, myalgia, gastrointestinal symptoms such as diarrhea and other airway symptoms. Half of the patients arise shortness in one week. In the case of rapid decay and

Progressive, such as the ARDS, septic shock, metabolic acidosis are difficult to correct and bleeding or dysfunction of the coagulation system in a few days. In some patients, symptoms appear mild, not even accompanied by fever. Most patients have a good prognosis, with a small part in the critical conditions even dying.

The increase in the number of COVID-19 cases lasts fairly quickly and there has been a spread outside of the Wuhan region and other countries. Globally it reported 51,857 cases of confirmation in 25 countries with 1,669 deaths (CFR 3.2\%). The country details and the number of cases as follows: 51,174 China confirmation case with 1,666 deaths, Japan (53 cases, 1 death and 355 cases on the cruise ship Japan Port), Thailand (34 cases), South Korea (29 cases), Vietnam (16 cases), Singapore (72 cases), United States (15 cases), Cambodia (1 case), Nepal ( 1 case), France (12 cases), Australia (15 cases), Malaysia (22 cases), Philippines ( 3 cases , 1 death), Sri Lanka (1 case), Canada ( 7 cases), Germany (16 cases), France (12 cases), Italy (3 cases), Russia ( 2 cases), United Kingdom (9 cases), Belgium (1 case), Finland (1 case), Spain ( 2 cases), Sweden (1 case), UAE (8 cases), and Egypt (1 case). Among these cases, there have been several reported health officers infected (WHO, 2020).

First reported on December 31, 2019, Coronavirus Disease 2019 (COVID-19) is a disease that is being plundering almost all over the world today, with the virus name Severe Acute Respiratory Syndrome Coronavirus-2 (SARS-COV2). Starting from the area of Wuhan, Hubei Province, China which reports the first time regarding the case of Pneumonia unknown cause. Data from the WHO website on March 7, 2010 was obtained a confirmation case of 90870 with a total deaths of 3112 people. 
STRADA Jurnal Ilmiah Kesehatan

DOI: $10.30994 /$ sjik.v9i1.324

ISSN: 2252-3847 (print); 2614-350X (online)

Vol.9 No.1. May 2020. Page.297-302

Based on the data as of February 14, 2020, the worldwide mortality rate was $2.1 \%$, in the city of Wuhan at $4.9 \%$ and Hubei province by 3.1\%. In Indonesia as of March 14, 2020 there are as many as 96 confirmed cases of COVID-19 with the number of deaths of 6 people and became the state to 65 a positive confirmation COVID-19. Overall mortality rate of COVID-19 is still smaller compared to the extraordinary occurrence of the other types of Coronavirus namely Severe Acute Respiratory Syndrome-Coronavirus (SARS-CoV) and Middle East Respiratory Syndrome-Coronavirus (MERS-CoV) respectively by $10 \%$ and $40 \%$.

Kemenkes RI (2020), said the positive case of Corona virus or Covid-19 in Indonesia continues to increase and now reaches 5,136 according to the Acceleration Task Force handling Covid19 data. There are additional new cases as 297. Of the number of positive cases in Indonesia, 469 is a case of death. However, 446 people successfully recovered or recovered from corona infections. To date, the number of Corona patients hospitalized in various health care centers reaches 4,221. Corona cases are most noted in DKI Jakarta, West Java, East Java and Central Java.

The number of people infected with Corona virus in Central Java in April 2020 was recorded as many as 342 people. Of these, 247 patients were still admitted to the Covid-19 referral hospital in Central Java.

Prevention of Covid-19 is influenced by several factors, one of which is knowledge. To date, knowledge of the COVID-19 infection in conjunction with pregnancy and the fetus is still limited and there has been no specific recommendation for the treatment of pregnant women with COVID-19. Based on such limited data and some cases in the previous Coronavirus treatment (SARS-CoV and MERS-CoV) and some cases of COVID-19, it is believed that pregnant women have a higher risk for severe illness, morbidity and mortality compared to the general population. Adverse reactions to the fetus in the form of preterm childbirth were also reported in pregnant women with COVID-19 infections. However, this information is very limited and is unclear whether this complication has a connection with the mother's infection. In two reports describing 18 pregnancies with COVID-19, all infected in the third trimester obtained clinical findings in pregnant mothers similar to those of unpregnant adults. Fetal and premature childbirth are found in some cases. In the two cases, a vaginal delivery and testing for SARS-CoV-2 were found negatively in all infants who were examined (the reproductive tract infection of the Indonesian Society of Obstetrics and gynaecology, 2020).

Until now it is also unclear whether the COVID-19 infection can pass the Transplasenta route towards the infant. Although there are some reports where the baby on the test obtained a positive examination with the presence of viruses a few moments after birth, but this research needs further validation about this transmission whether it occurs in the womb or in postnatal. There is currently no data directing for an increased risk of miscarriage associated with COVID19. (The reproductive tract infection of Indonesian obstetrics and Gynaecological Society, 2020). Midwives should do anamnesis about the history of a pregnant mother with symptoms of fever and infection of the upper respiratory tract.

Based on preliminary study conducted in March 2020 in hospital X, from 10 midwives who work in the hospital 6 have less knowledge to the handling of Garry 19. So the authors are interested to take research on the knowledge relationship of midwives to the handling of Corona virus infection (COVID 19) on maternity mothers in hospital X. 


\section{METHOD}

This research uses quantitative methods with the design of a cross sectional. This research sample amounted to 30 midwives with sample techniques using sampling quotas. This research uses a questionnaire with 10 questions. Analytical techniques using univariate and bivariate. Univariate describes the characteristics of respondents, while sufficient to analyse relationships using Chi Square test.

\section{RESULT}

From the research that has been done, it is obtained the characteristic data of respondents, namely age and education of the respondents which can be seen in Table 1 and Table 2 .

Table 1. Age Distribution of Respondents

\begin{tabular}{lllll}
\hline \multirow{2}{*}{ No } & \multirow{2}{*}{ Age } & \multicolumn{3}{c}{ Total } \\
\cline { 3 - 5 } & & 20 & $\mathrm{~N}$ & \\
\hline 1 & $20-35$ & 10 & 66,7 & \\
2 & $>35$ & 30 & 33,3 & \\
\hline TOTAL & & & 100 & \\
\hline
\end{tabular}

Table 1 show that the age of respondents is in the range of 20-35 years with the majority aged 34 years at $40 \%$.

Table 2. Distribution of Get Information Respondent

\begin{tabular}{|c|c|c|c|}
\hline \multirow{2}{*}{ No } & \multirow{2}{*}{ Category } & \multicolumn{2}{|c|}{ Total } \\
\hline & & $\mathrm{N}$ & $\%$ \\
\hline 1 & Never & 16 & 53,3 \\
\hline 2 & Ever & 14 & 46,7 \\
\hline TO & & 30 & 100 \\
\hline
\end{tabular}

Table 2 shows that as many as 53,3\% of respondents had never get information about handling covid 19.

Table 3 . Research Variable Description

\begin{tabular}{clllll}
\hline Variable & $\mathrm{n}$ & Min & Maks & Mean & SD \\
\hline Knowledge & 30 & 5 & 15 & 11.29 & 2.67 \\
\hline
\end{tabular}

Based on table 3 known minimum value, maximum value, mean value and standard deviation. The table above is for measuring variables with a continuous scale, both dependent variables and independent variables. The Mean illustrates the average value, while the standard deviation (SD) illustrates how much data is varied. If a small SD value is an indication that the data is representative.

Table 4. Knowledge Value of Midwives on Corona Infection Handling (Covid 19)

\begin{tabular}{llll}
\hline Variable & Category & $\mathrm{n}$ & $\%$ \\
\hline Knowledge & Low & 20 & 66,7 \\
& High & 10 & 33,3 \\
\hline
\end{tabular}


Based on table 4 known knowledge of midwives about the handling of Covid 19 tends to have low knowledge as much as 20 people $(66.7 \%)$.

Table 5. Chi-Square Analysis results

\begin{tabular}{llll}
\hline & OR & CI 95\% & P \\
\cline { 2 - 4 } Knowledge & 0.08 & $0.04-0.16$ & $<0.001$ \\
\hline
\end{tabular}

Based on table 5 results of analysis bivariate using Chi Square test showed that low knowledge about Garry 19 has a probability of 0.08 times lower for midwives in handling Garry 19 on maternity mothers. Statistic significantly $(\mathrm{OR}=0.08$ : CI 95\% $=0.04-0.16, \mathrm{p}<0.001)$. The results of Chi Square analysis to know the knowledge relationship of midwives to the handling of Corona virus (Covid 19) infection in maternity mothers, obtained the value $\mathrm{P}$ of $<0.001$. The $\mathrm{P}$ value would be meaningful when $<0.005$. Because of the $\mathrm{P}$ value gained in the study of < 0.005 , the value of this $\mathrm{p}$ is meaningful. This indicates there is a meaningful relationship between the knowledge of midwives to the handling of Corona virus infection (Covid 19) in maternity mothers. Midwive with a high level of knowledge is likely in the handling of Garry 19 is also good.

\section{DISCUSSION}

This corresponds to the statement Setyani (2016); Regar (2016), that whether or not the understanding of one person is influenced by the source of information. The more people get information related to the handling of Covid 19, the more knowledge is being obtained so that the bias handles maternity mothers who are experiencing Covid 19. In addition, the reference books related to the handling of Covid 19 for maternity mothers are still minimal. Respondents actually have not understood about corona infections. It is backed with the background of respondents whose majority has not received much information regarding the handling of Coovid 19. With the in can be deduced someone who has a broad insight related Garry 19 will be more capture or obtain information.

According to Owen et al (2015), the knowledge of one should not be gained from formal education alone but can be a non-formal education through mass media, electronic media and individual media such as advice or counseling. The knowledge of respondents about Covid 19 affects a person's perception, in this case the perception of the handling of Covid 19.

Based on the research of Yuliana (2020), the knowledge of a person affects health indicators indirectly. The knowledge will affect behavior, then the behavior of health will affect the increasing indicators of public health. In this case, a good knowledge of Garry 19 will improve behavior in the handling of Covid 19. This illustrates that the level of knowledge of midwives about Covid 19 can affect the handling of Covid 19.

\section{CONCLUSION}

Based on results and discussion, it can be concluded that the knowledge of midwives related to the treatment of Corona virus infection (Covid 19) is connected and statistically significant $(\mathrm{OR}=0.08$; CI $95 \%=0.04$ to $0.16 ; \mathrm{p}<<0.001)$. 
STRADA Jurnal Ilmiah Kesehatan

DOI: $10.30994 /$ sjik.v9i1.324

ISSN: 2252-3847 (print); 2614-350X (online)

Vol.9 No.1. May 2020. Page.297-302

\section{REFERENCES}

Buku Saku Pencegahan Covid 19. (2020). Kesiapsiagaan Menghadapi Infeksi COVID 19. https://www.kemkes.go.id/folder/view/01/structure-penanggulangan-krisis-bukupedoman.html

Gugus Tugas Percepatan Penanganan Covid 19. (2020). Situasi Virus Covid 19 di Indonesia. https://covid19.go.id.

Owen et al. (2015). Model Penyebaran Penyakit Menular Mers-CoV. Universitas Parahyangan.

Pokja Infeksi Saluran Reproduksi Perkumpulan Obstetri dan Ginekologi Indonesia. (2020). Rekomendasi Penanganan Infeksi Virus Corona (Covid 19) Pada Maternal (Hamil, Bersalin dan Nifas). https://pogi.or.id/publish/wpcontent/uploads/2020/03/Rekomendasi-Penanganan-Infeksi-COVID-19-padamaternal.pdf

WHO. (2020). Corona virus disease (COVID 19). https://www.who.int/indonesia/news/novelcoronavirus

Kementrian Kesehatan Republik Indonesia. (2020). Novel Corona Virus (NCOV). https://www.kemkes.go.id/resources/download/info-terkini/COVID19/TENTANG\%20NOVEL\%20CORONAVIRUS.pdf

\begin{tabular}{llcl}
\hline Menghadapi Outbreak Novel & $\begin{array}{c}\text { (2020). Kesiapan Kemenkes dalam } \\
\text { Corona }\end{array}$ aviris & (2019-nCov).
\end{tabular}
https://www.papdi.or.id/pdfs/817/dr\%20Siti\%20Nadia\%20-\%20Kemenkes\%20RI.pdf

Yuliana. (2020). Corona Virus Diseases (Covid 19); Sebuah Tinjauan Literatur. Wellness and Healthy Magazine., Vol 2 (1), Hal 187-192. 